Proceedings of the 12th International Symposium on Physics of Materials, Prague, September 4-8, 2011

\title{
Structure and Properties of Fe-Ni-Al-Si Alloys Produced by Powder Metallurgy
}

\author{
P. Novák*, L. Mejzlíková, V. Hošek, M. Martínek, I. Marek and A. Michalcová \\ Department of Metals and Corrosion Engineering, Institute of Chemical Technology \\ Technická 5, 16628 Prague, Czech Republic
}

\begin{abstract}
Reactive sintering powder metallurgy is a simple alternative to conventional melting and powder metallurgy processes. During this process, pressed powder mixture of pure metals or other precursors is transformed into bulk intermediary phases by thermally activated in situ reaction. This process was previously tested on $\mathrm{Fe}-\mathrm{Al}$ and $\mathrm{Fe}-\mathrm{Al}-\mathrm{Si}$ alloys. Positive effect of silicon on the reactive sintering behaviour was determined, leading to the development of novel carbon-free high-silicon FeAl20Si20 alloy (given in wt\%). In this work, the effect of nickel on the pressureless reactive sintering of $\mathrm{Fe}-\mathrm{Al}-\mathrm{Si}$ pressed powder mixtures was studied. To explain the nickel influence, differential thermal analysis was utilized. Microstructure, phase composition and porosity of the FeAl20Si20Nix $(x=0,5,10,20 \mathrm{wt} \%)$ alloys was described. Hardness, wear resistance, high-temperature oxidation resistance and thermal stability were evaluated as functions of nickel content. Results showed that porosity decreases with growing nickel content down to less than 3 vol.\%. Oxidation rate of these alloys is more than 10 times lower than that of original FeAl20Si20 alloy. Thermal stability and abrasive wear resistance of these alloys is also superior to $\mathrm{Fe}-\mathrm{Al}$ and $\mathrm{Fe}-\mathrm{Al}-\mathrm{Si}$ materials.
\end{abstract}

PACS: 61.66.Dk, 62.20.Qp

\section{Introduction}

The positive effect of aluminium on the oxidation resistance on iron-based alloys has been known already for more than 100 years [1]. Therefore, high-aluminium alloys have been recognized as promising materials for high-temperature applications. These alloys, being formed by $\mathrm{Fe}_{3} \mathrm{Al}$ or $\mathrm{FeAl}$ ordered phases, are characterized by very good high-temperature corrosion resistance in oxidizing and sulphidizing environments together with low cost of the constituents and lower density (5.7 $\mathrm{g} \mathrm{cm}^{-3}$ for $\left.\mathrm{FeAl}[2]\right)$ than that of common metallic high-temperature materials (nickel alloys and heat-resistant steels). However, their low room-temperature ductility [3] and problems with production caused that these materials are applied only in special applications up to now [4]. Possible production routes of iron aluminides concern casting technology $[1,4,5]$, hot working, or powder metallurgy processes.

In the case of powder metallurgy technologies, alloyed $\mathrm{Fe}-\mathrm{Al}$ powders show poor compressibility and sinterability. Therefore, reactive sintering is considered as a promising alternative production route [6]. Reactive sintering is a technology, where pure elements or other suitable precursors are transferred into desired compounds by a thermally activated in situ chemical reaction during sintering process [6]. By a pressureless reactive sintering of $\mathrm{Fe}-\mathrm{Al}$ pressed powder mixtures, relative density of maximum $75 \%$ can be obtained [7]. A promising solution of the problem with porosity consists either in pressure-assisted reactive sintering or alloying with other element, modifying the reaction mechanism.

* corresponding author; e-mail: panovak@vscht.cz
In our previous work, silicon was found to reduce the porosity of $\mathrm{Fe}-\mathrm{Al}$ alloys produced by reactive sintering $[8,9]$. Silicon added to $\mathrm{Fe}-\mathrm{Al}$ alloys completely modifies the intermetallic phases' formation mechanism. Silicon-containing phases ( $\mathrm{Fe}-\mathrm{Si}, \mathrm{Fe}-\mathrm{Al}-\mathrm{Si}$ ) grow towards the molten Al-Si alloy while the iron aluminides follow the direction to the core of the iron particles as in the $\mathrm{Fe}-\mathrm{Al}$ binary system. It helps to fill the spaces between iron particles in the pressed powder mixture [9]. In addition, silicon forms an eutectic with aluminium which melts at lower temperature than aluminium $\left(577^{\circ} \mathrm{C}\right)$. Therefore the time of the melt existence during heating prior the formation of intermetallics is prolonged [8]. Due to this fact, melt is able to fill the pores between iron particles. Optimum alloy composition was previously determined as FeAl20Si20 (given in wt\%) [8]. In this work, the effect of partial replacement of iron by nickel, as a known aluminide-forming element, on the structure and properties of $\mathrm{Fe}-\mathrm{Al}-\mathrm{Si}$ alloys was studied.

\section{Experimental}

$\mathrm{Fe}-\mathrm{Al}-\mathrm{Si}-\mathrm{Ni}$ alloys produced by reactive sintering of iron, AlSi30 alloy, silicon and nickel powders were studied. Powder of AlSi30 alloy with particle size of 200$600 \mu \mathrm{m}$ was prepared by mechanical machining. Silicon powder ( $99.995 \%$ purity) with the particle size below $50 \mu \mathrm{m}$ was obtained by mechanical milling. Iron and nickel powders were used in a form of commercially available powder of p.a. purity and a grain size below $10 \mu \mathrm{m}$. Green bodies of Fe-Al-Si-Ni alloys containing 20 wt $\%$ of aluminium and silicon and $0-20 \mathrm{wt} \%$ of nickel were produced by blending of the above mentioned powders and uniaxial pressing at the laboratory temperature by a pressure of $320 \mathrm{MPa}$ using Heckert FPZ100/1 universal loading machine. 
Reactive sintering of $\mathrm{Fe}-\mathrm{Al}-\mathrm{Si}$ pressed powder mixtures was carried out at the temperature of $1100^{\circ} \mathrm{C}$ for $30 \mathrm{~min}$ in the electric resistance furnace with the heating rate over $300 \mathrm{~K} \mathrm{~min}^{-1}$ according to previous results published in [10]. Microstructure of the prepared materials was observed by Olympus PME3 light microscope. AxioVision 4.7 and ImageJ $1.44 p$ programs were applied for the digital image recording and processing. Phase composition was determined by X-ray diffraction (XRD) analysis using a PANalytical X'Pert Pro X-ray diffractometer and Tescan Vega 3 LMU scanning electron microscope equipped with Oxford Instruments INCA 350 EDS analyser.

Hardness of the prepared materials was tested by the Vickers method with the load of $10 \mathrm{~kg}$ (HV 10). The abrasive wear resistance was evaluated by using a modification of the "pin-on-disc" method, where "pin" was the tested material and "disc" was a P1200 grinding paper. The applied load (normal force) was $5.8 \mathrm{~N}$ and the sliding distance was defined as $2.5 \mathrm{~km}$. The wear rate was calculated from the measured weight losses by Eq. (1) [11]:

$$
w=\frac{\Delta m 1000}{\rho l F_{N}},
$$

where $w\left[\mathrm{~mm}^{3} \mathrm{~m}^{-1} \mathrm{~N}^{-1}\right], \Delta m[\mathrm{~g}], \rho\left[\mathrm{g} \mathrm{cm}^{-3}\right], F_{N}[\mathrm{~N}]$ and $l[\mathrm{~m}]$ are wear rate, weight loss, normal force and sliding distance on the grinding paper, respectively. The density of samples was determined by the Archimedes method.

High-temperature oxidation resistance was studied by the cyclic oxidation tests at $800^{\circ} \mathrm{C}$ for $432 \mathrm{~h}$. During these tests, samples were heated for $48 \mathrm{~h}$ cycles. Each cycle consisted of heating to the test temperature, air-cooling to the laboratory temperature, weighing and heating up to the test temperature. Oxidation rate of the alloys is presented as a dependence of the specific weight gain, i.e. the weight change over the exposed surface area, on the oxidation duration. To quantify the oxidation rate of tested alloys, parabolic rate constant was calculated according to Eq. (2):

$$
k_{\mathrm{p}}=\left(\frac{\Delta m}{A}\right)^{2} \frac{1}{t},
$$

where $k_{\mathrm{p}}\left[\mathrm{g}^{2} \mathrm{~m}^{-4} \mathrm{~s}^{-1}\right], \Delta m[\mathrm{~g}], A\left[\mathrm{~m}^{2}\right]$ and $t[\mathrm{~s}]$ are parabolic constant, weight gain, exposed surface area and time, respectively.

Thermal stability of the alloys was studied by hardness measurement after annealing at $800^{\circ} \mathrm{C}$.

\section{Results and discussion}

\subsection{Microstructure and phase composition}

Ternary FeAl20Si20 alloy produced by reactive sintering at $1100{ }^{\circ} \mathrm{C}$ is composed of $\mathrm{FeSi}, \mathrm{FeAl}$ and $\mathrm{Al}_{2} \mathrm{Fe}_{3} \mathrm{Si}_{3}$ phases (Fig. 1a), as proved in our previous paper [10]. This material exhibits significantly lower porosity (approximately 10 vol.\%) than the binary $\mathrm{Fe}-\mathrm{Al}$ alloys obtained by the same process. The positive effect of silicon on the reactive sintering behaviour was proved in [9].

When nickel is introduced to this system, porosity of the alloy reduces down to the value of $3 \mathrm{wt} \%$ for the al-

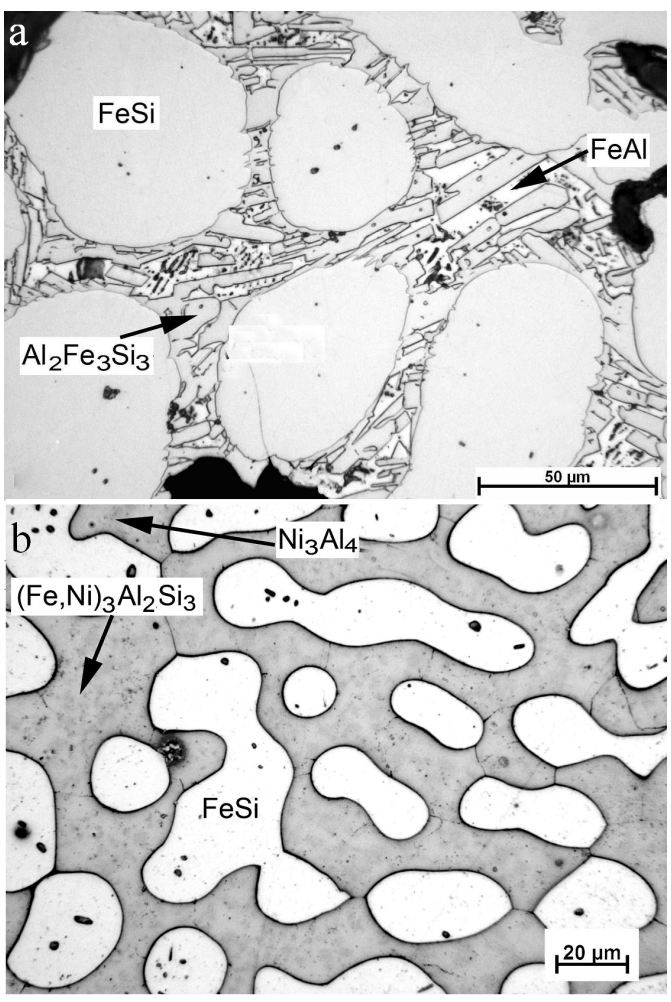

Fig. 1. Microstructure of (a) FeAl20Si20 [10], (b) FeAl20Si20Ni10 alloys produced by reactive sintering at $1100^{\circ} \mathrm{C}$ for $30 \mathrm{~min}$.

TABLE I

Structural parameters and properties of $\mathrm{Fe}-\mathrm{Al}-\mathrm{Si}-\mathrm{Ni}$ alloys.

\begin{tabular}{c|c|c|c|c}
\hline \hline Ni content [wt\%] & $\mathbf{0}$ & $\mathbf{5}$ & $\mathbf{1 0}$ & $\mathbf{2 0}$ \\
\hline porosity [vol.\%] & 11 & 7 & 5 & 3 \\
FeSi size [ $\mu \mathrm{m}]$ & 55 & 40 & 23 & 13 \\
FeSi fraction [vol.\%] & 65 & 60 & 44 & 28 \\
hardness $(\mathrm{HV} \mathrm{10)}$ & 623 & 801 & 805 & 803 \\
$w \times 10^{4}\left[\mathrm{~mm}^{3} \mathrm{~m}^{-1} \mathrm{~N}^{-1}\right]$ & 4.3 & 1.9 & 1.2 & 0.5 \\
FeSi size $[\mu \mathrm{m}]$ & & & & \\
after annealing & 65 & 45 & 26 & 14 \\
$\left(80{ }^{\circ} \mathrm{C}, 336 \mathrm{~h}\right)$ & & & & \\
$\mathrm{HV} 10$ after annealing & 580 & 798 & 802 & 805 \\
$\left(80{ }^{\circ} \mathrm{C}, 336 \mathrm{~h}\right)$ & & & &
\end{tabular}

loy containing $20 \mathrm{wt} \%$ of nickel, see Table I. Microstructure of the nickel-containing alloys is composed of $\mathrm{FeSi}$ iron silicide, $(\mathrm{Fe}, \mathrm{Ni})_{3} \mathrm{Al}_{2} \mathrm{Si}_{3}$ phase (Fig. 1b) and small amount of $\mathrm{Ni}_{3} \mathrm{Al}_{4}$ aluminide, seen as darker grey regions in $\left(\mathrm{Fe}, \mathrm{Ni}_{3} \mathrm{Al}_{2} \mathrm{Si}_{3}\right.$ phase in Fig. 1b. This phase composition was proved by XRD and energy dispersive spectroscopy (EDS). Nickel dissolves predominantly in non-silicide phases (ternary phase and aluminide). Therefore, average size of FeSi particles reduces as well as the volume fraction of this phase decreases when nickel content is growing. Therefore, an increase of nickel concentration to $20 \mathrm{wt} \%$ causes the presence of unreacted 
silicon particles, which may affect mechanical properties negatively.

\subsection{Differential thermal analysis}

The effect of nickel on the phases' formation during reactive sintering was studied by differential thermal analysis (DTA) by heating the $\mathrm{Fe}-\mathrm{Al}-\mathrm{Si}$ and $\mathrm{Fe}-\mathrm{Al}-\mathrm{Si}-\mathrm{Ni}$ pressed powder mixtures by the rate of $10 \mathrm{~K} \mathrm{~min}^{-1}$. In ternary $\mathrm{Fe}-\mathrm{Al}-\mathrm{Si}$ system, one endothermic effect and three exothermic ones can be observed on the heating curve (Fig. 2). Endothermic effect at approximately $580^{\circ} \mathrm{C}$ accompanies the melt formation by the eutectic transformation in $\mathrm{Al}-\mathrm{Si}$ system. On the interface between solid iron and liquid Al-Si alloy, the exothermal formation of $\mathrm{Al}_{2} \mathrm{FeSi}$ phase takes place at $650-700{ }^{\circ} \mathrm{C}$. This phase undergoes a reaction with residual silicon and iron producing $\mathrm{Al}_{2} \mathrm{Fe}_{3} \mathrm{Si}_{3}$ phase. At $1050{ }^{\circ} \mathrm{C}$ a decomposition of these phases to $\mathrm{FeAl}$ and FeSi phases starts $[8,10]$.

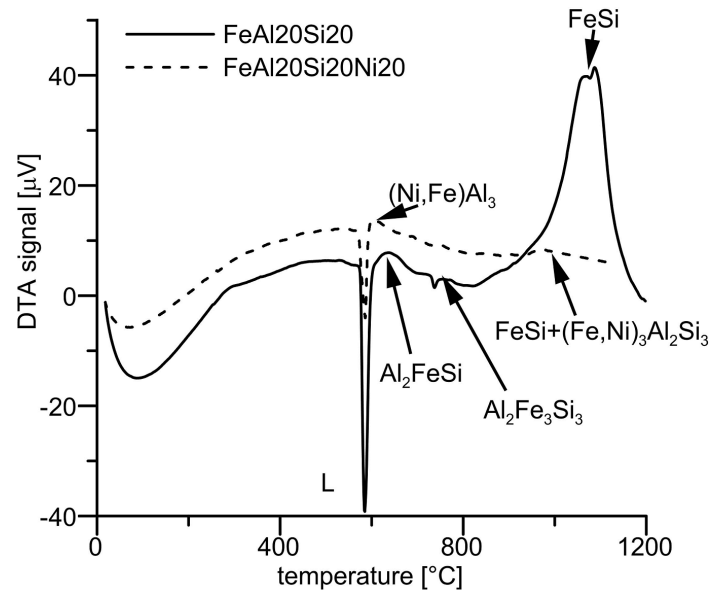

Fig. 2. DTA heating curve of FeAl20Si20 and FeAl20Si20Ni20 alloys.

In $\mathrm{Fe}-\mathrm{Al}-\mathrm{Si}-\mathrm{Ni}$ system, only one endothermic and two exothermic reactions were observed on the heating curve, arising at approximately 600 and $1000^{\circ} \mathrm{C}$. The observed thermal effects are much smaller than in $\mathrm{Fe}-\mathrm{Al}-\mathrm{Si}$ system. To determine the phases' formation sequence, the FeNi20Al20Si20 pressed powder mixture was heated rapidly to $700^{\circ} \mathrm{C}$ and water quenched consequently. The chemical composition of the present phases was investigated by the SEM+EDS. It was proved that the first exothermal peak on the heating curve belongs to the formation of $(\mathrm{Ni}, \mathrm{Fe}) \mathrm{Al}_{3}$ phase. This phase probably reacts with iron and silicon at $1000^{\circ} \mathrm{C}$, producing iron silicide and $(\mathrm{Fe}, \mathrm{Ni})_{3} \mathrm{Al}_{2} \mathrm{Si}_{3}$ phase. To determine the reaction mechanism exactly, in situ $\mathrm{X}$-ray analysis is currently carried out.

To describe the thermal effects during the real reactive sintering process, samples were placed to a preheated furnace and reactive sintering progress was recorded in situ by a CCD camera (Fig. 3). In this process, reactions start after longer time in $\mathrm{Fe}-\mathrm{Al}-\mathrm{Si}-\mathrm{Ni}$ system, but the thermal effect, observed as a "flame ignition", is much higher in

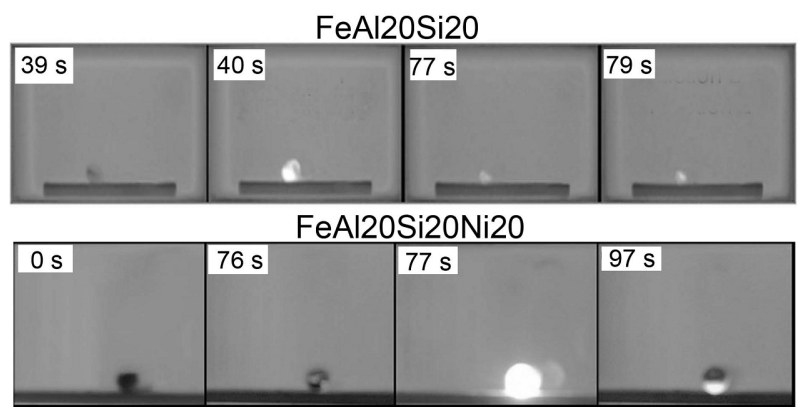

Fig. 3. Reactive sintering progress in $\mathrm{Fe}-\mathrm{Al}-\mathrm{Si}$ and $\mathrm{Fe}-$ $\mathrm{Al}-\mathrm{Si}-\mathrm{Ni}$ pressed powder mixtures at $1100^{\circ} \mathrm{C}$.

this powder mixture. This result is in a disagreement with the DTA presented above. The reason for this behaviour lies in a different heating rate. In $\mathrm{Fe}-\mathrm{Al}-\mathrm{Si}-\mathrm{Ni}$ system, higher heating rate is probably needed to initiate the reactions properly.

\subsection{Mechanical and tribological properties}

The influence of nickel on hardness and abrasive wear resistance of $\mathrm{Fe}-\mathrm{Al}-\mathrm{Si}$ alloys is summarized in Table I. Nickel increases the hardness of $\mathrm{Fe}-\mathrm{Al}-\mathrm{Si}$ alloys up to approximately $800 \mathrm{HV} 5$. Addition of nickel to Fe-Al-Si alloys also caused an enormous improvement of the wear resistance. There are two possible reasons for such behaviour - the hardness increase and elimination of brittle phases. In this case, hardness increased by nickel alloying. In addition, nickel eliminates the formation of pores and cracks in the material (see Fig. 1a). Presence of volume defects in FeAl20Si20 alloy is probably a consequence of lattice changes between $\mathrm{Al}_{2} \mathrm{FeSi}, \mathrm{Al}_{2} \mathrm{Fe}_{3} \mathrm{Si}_{3}$, $\mathrm{FeAl}$, and FeSi phases during reactive sintering. Pores and cracks could decrease the wear resistance enabling the particles' spallation.

\subsection{Oxidation resistance and thermal stability}

Oxidation resistance of $\mathrm{Fe}-\mathrm{Al}-\mathrm{Si}-\mathrm{Ni}$ alloys with various content of nickel is plotted in Fig. 4 as a dependence of weight gain over the surface area vs. oxidation duration. It shows that even $5 \mathrm{wt} \%$ of nickel added to the $\mathrm{Fe}-\mathrm{Al}-\mathrm{Si}$ alloy reduces its oxidation rate at $800^{\circ} \mathrm{C}$ more than 10 times. The oxidation rate also increases with further addition of nickel up to $20 \mathrm{wt} \%$. To explain the behaviour, EDS and XRD analyses of the oxide layers were carried out. In Fe-Al-Si alloy, the oxide layer comprises $\mathrm{Al}_{2} \mathrm{O}_{3}$ as the dominant phase and $\mathrm{Fe}_{2} \mathrm{O}_{3}$ (Table II). While aluminium oxide is a protective layer responsible for good oxidation resistance, the effect of $\mathrm{Fe}_{2} \mathrm{O}_{3}$ on the oxidation resistance is detrimental. This oxide is known from heat-resistant steels to cause a poor adherence of the oxide layer. In the case of $\mathrm{Fe}-\mathrm{Al}-\mathrm{Si}-\mathrm{Ni}$ alloys, iron oxide was not detected by XRD on the surface of oxidized samples. This result was confirmed by the EDS analysis. By this method, very low content of iron (less than $2 \mathrm{wt} \%$ ) was detected in the oxide layer on FeAl20Si20Ni20 alloy, while FeAl20Si20 alloy's oxide layer contained more than 
$15 \mathrm{wt} \% \mathrm{Fe}$. The reason probably lies in the modification of activity of aluminium and iron in present phases when nickel is added.

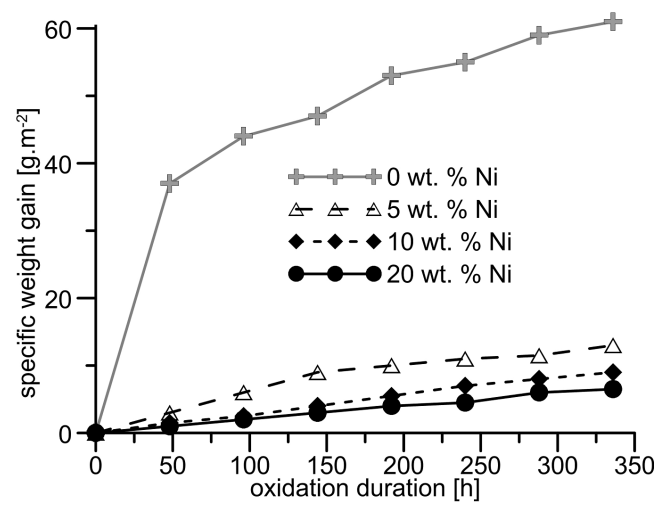

Fig. 4. Specific weight gain vs. duration of oxidation at $800{ }^{\circ} \mathrm{C}$ in air.

TABLE II

Phase and chemical composition of the oxide layers on $\mathrm{Fe}-\mathrm{Al}-\mathrm{Si}$ and $\mathrm{Fe}-\mathrm{Al}-\mathrm{Si}-\mathrm{Ni}$ alloys, oxidized at $800^{\circ} \mathrm{C}$ for $336 \mathrm{~h}$ in air (XRD, EDS).

\begin{tabular}{c|c|c|c|c|c|c}
\hline \hline \multirow{2}{*}{ Alloy } & \multirow{2}{*}{$\begin{array}{c}\text { Phase } \\
\text { composition }\end{array}$} & \multicolumn{5}{|c}{ Chemical composition [wt\%] } \\
\cline { 3 - 7 } & $\mathrm{Al}_{2} \mathrm{O}_{3}, \mathrm{Fe}_{2} \mathrm{O}_{3}$ & 36.3 & 42.9 & 5.2 & 15.6 & 0 \\
\hline FeAl20Si20 & $\mathrm{Al}_{2} \mathrm{O}_{3}$ & 63.4 & 32.7 & 1.7 & 1.7 & 0.5
\end{tabular}

TABLE III

Parabolic rate constants $k_{\mathrm{p}}\left[\times 10^{-5} \mathrm{~g}^{2} \mathrm{~m}^{-4} \mathrm{~s}^{-1}\right]$ of $\mathrm{Fe}-\mathrm{Al}-\mathrm{Si}-\mathrm{Ni}$ alloys' oxidation at $800{ }^{\circ} \mathrm{C}$.

\begin{tabular}{c|c|c|c|c}
\hline \hline Oxidation & \multicolumn{4}{|c}{ Nickel content [wt\%] } \\
\cline { 2 - 5 } duration [h] & 0 & 5 & 10 & 20 \\
\hline 48 & 792 & 5 & 1 & 5 \\
96 & 560 & 10 & 2 & 1 \\
144 & 426 & 16 & 3 & 2 \\
192 & 404 & 15 & 4 & 2 \\
240 & 305 & 14 & 6 & 2 \\
288 & 336 & 13 & 6 & 4 \\
336 & 308 & 14 & 7 & 4
\end{tabular}

The above described differences in oxidation are quantified as parabolic rate constants $\left(k_{\mathrm{p}}\right)$ in Table III. It can be seen that the parabolic constants calculated for each cycle are almost independent of the oxidation duration in the case of all nickel-containing alloys. It shows excellent protective effect of the oxide layer against further oxidation. In $\mathrm{Fe}-\mathrm{Al}-\mathrm{Si}$ alloy without nickel, the oxidation rate is high at the early stages of oxidation. After that, the $k_{\mathrm{p}}$ value continuously decreases with oxidation duration. The reason of this behaviour probably lies in higher porosity of this alloy. At early stages of oxidation, the open pores are filled with oxides. Therefore, the active surface area is reduced and oxidation rate decreases [12].

Thermal stability of $\mathrm{Fe}-\mathrm{Al}-\mathrm{Si}-\mathrm{Ni}$ alloys was tested by comparing the hardness before and after annealing at
$800{ }^{\circ} \mathrm{C}$ for $300 \mathrm{~h}$. Nickel-containing alloys were found to keep constant hardness, while $\mathrm{Fe}-\mathrm{Al}-\mathrm{Si}$ alloy without nickel addition softened during annealing (Table I). Thermal stability of mechanical properties is closely connected with the stability of microstructure. In this work, this parameter is represented by the dependence of $\mathrm{FeSi}$ silicide particle size after annealing at $800^{\circ} \mathrm{C}$ for $300 \mathrm{~h}$ on the nickel content. It shows that the higher is the content of nickel, the lower is the coarsening of the silicide particles, see Table I.

\section{Conclusion}

In this work, the effect of nickel addition to $\mathrm{Fe}-\mathrm{Al}-\mathrm{Si}$ alloys was tested. Powder metallurgy using reactive sintering was applied to produce these materials. It was found that nickel addition significantly improves the high-temperature oxidation resistance in air as well as the abrasive wear behaviour. $\mathrm{Fe}-\mathrm{Al}-\mathrm{Si}-\mathrm{Ni}$ alloys also can be successfully produced by reactive sintering, achieving a porosity down to 3 vol.\% according to nickel content. Therefore, these novel alloys can be the candidate materials for high temperature applications or e.g. for the manufacture of special tools. To prove the applicability, thorough testing of other properties of these materials will follow.

\section{Acknowledgments}

This work was financially supported by the KAN300100801 research project of the Grant Agency of ASCR.

\section{References}

[1] P. Kratochvíl, Intermetallics 16, 587 (2008).

[2] http://www.reade.com/Products/Aluminides/ iron_aluminide.html.

[3] P. Haušild, J. Siegl, P. Málek, V. Šíma, Intermetallics 17, 680 (2009).

[4] R.R. Judkins, U.S. Rao, Intermetallics 8, 1347 (2000).

[5] P.A. Mcquay, V.K. Sikka, in: Encyclopedia of Materials: Science and Technology, Pergamon Press, London 2001, p. 1011.

[6] S. Jozwiak, K. Karczewski, Z. Bojar, Intermetallics 18, 1332 (2010).

[7] U.S. Patent No. 5,269,830.

[8] P. Novák, V. Knotek, J. Šerák, A. Michalcová, D. Vojtěch, Powder Metall. 54, 167 (2011).

[9] P. Novák, V. Knotek, M. Voděrová, J. Kubásek, J. Šerák, A. Michalcová, D. Vojtěch, J. Alloys Comp. 497, 90 (2010).

[10] P. Novák, A. Michalcová, M. Voděrová, M. Šíma, J. Šerák, D. Vojtěch, K. Wienerová, J. Alloys Comp. 493, 81 (2010).

[11] P. Novák, D. Vojtěch, J. Šerák, Surf. Coat. Technol. 200, 5229 (2006).

[12] P. Novák, M. Zelinková, J. Šerák, A. Michalcová, M. Novák, D. Vojtěch, Intermetallics 19, 1306 (2011). 